\title{
Transactivation and reactivation capabilities of temperature-dependent p53 mutants in yeast and human cells
}

\author{
JANA JAGOSOVA $^{1,2}$, LENKA PITROVA ${ }^{1,2}$, JANA SLOVACKOVA ${ }^{1}$, \\ BARBORA RAVCUKOVA $^{3}$, JAN SMARDA ${ }^{2}$ and JANA SMARDOVA ${ }^{1,2}$
}

${ }^{1}$ Department of Pathology, University Hospital Brno, Jihlavska 20, $62500 \mathrm{Brno} ;{ }^{2}$ Department of Experimental Biology, Faculty of Science, Masaryk University, Kotlarska 2, 61137 Brno; ${ }^{3}$ Molecular Genetics Laboratory, Centre for

Cardiovascular Surgery and Transplantation, Vystavni 17/19, 60300 Brno, Czech Republic

Received March 14, 2012; Accepted May 22, 2012

DOI: 10.3892/ijo.2012.1520

\begin{abstract}
The p53 protein is a sequence-specific transcription factor controlling the expression of multiple genes and protecting cells from oncogenic transformation. In many tumors, the p53 protein is completely or partially inactivated by mutations in the $p 53$ gene. We analyzed the transactivating activity of nine human temperature-dependent (td) p53 mutants in yeast cells. Mutations in seven of them were localized in the $\beta$-sandwich-coding region of the $p 53$ gene, eight p53 mutants were temperature-sensitive and the R283C mutant was coldsensitive. Patterns of their transactivation abilities towards three different responsive elements, the extent of their temperature dependency as well as discriminativity, were considerably variable. Similarly, their capacity to become reactivated by amifostine varied from complete resistance to high sensitivity. Transactivation abilities and temperature dependency of six p53 td mutants were determined in transiently-transfected H1299 human cells and revealed substantial concordance between the activity patterns of the p53 mutants in yeast and human cells. We concluded that the td p53 mutants do not comprise a uniform group, therefore, the behavior of each mutant has to be tested individually.
\end{abstract}

\section{Introduction}

The p53 protein is a sequence-specific transcription factor controlling the expression of multiple genes, thus participating in the regulation of the cell cycle, apoptosis, senescence and genome stability. This protein acts as tumor suppressor protecting cells from oncogenic transformation. p53 dysfunction is a prerequisite for tumor development. Somatic p53 mutations are present in almost half of all cancer cases in

Correspondence to: Professor Jana Smardova, Department of Pathology, University Hospital, Jihlavska 20, 62500 Brno, Czech Republic

E-mail: janasmarda@seznam.cz

Key words: p53, transactivation, temperature-dependent p53 mutants, discriminating p 53 mutants, functional analysis of separated alleles in yeast almost all types of cancer. Germ-line p53 mutations are associated with the Li-Fraumeni syndrome, a rare cancer syndrome predisposing the patients to a broad spectrum of tumors.

There are multiple ways of functional inactivation of p53, including aberrations of its upstream or downstream mediators and overexpression of its negative regulators. Direct mutation of the p53 gene is the most frequent mechanism of p53 inactivation. According to the latest version of the IARC TP53 mutation database (R15 from November 2010 at http://www-p53.iarc.fr) (1), the most common are single-base substitutions representing $>80 \%$ of all detected p53 mutations. They are distributed throughout the coding region with strong prevalence in its part coding for the central DNA-binding domain.

The functional impact of the p53 mutations is complex. Although many mutations cause complete loss of p53 function, some result in its reduction or modification. Modified p53 often exhibits an altered spectrum of transactivated genes or changes in dependency on external conditions, such as temperature or $\mathrm{pH}(2,3)$. Partial loss of activity is an important property of some p53 mutants and is associated with a milder impact on the clinical course of the Li-Fraumeni syndrome compared to complete $\mathrm{p} 53$ inactivation (4). The studies on $\mathrm{p} 53$ performed in pediatric adrenocortical carcinoma $(5,6)$ provided formulation of 'the p53 mutation gradient effect', a concept connecting the degree of p53 activity with its impact on tumors (7).

The partially functional mutations comprise approximately $10-11 \%$ of all p53 mutations $(8,9)$. The temperature-dependent (td) p53 mutants, the prototypes of the p53 mutants with incomplete and conditionally lost activity have attracted great interest as they represent potential targets for the pharmacological rescue of p53 function $(10,11)$. Several studies deal with the detection and analysis of td p53 mutations; they present a reasonably long list of td p53 mutations and provide several interesting insights into understanding their significance. It has been shown that td $\mathrm{p} 53$ mutations are not as rare as had previously been thought and that they comprise approximately $10 \%$ of p53 mutations detected in tumors and cause single amino-acid substitutions. The td mutations are usually clustered in the $\beta$-sandwich-coding region causing predominantly hydrophobic large-to-small substitutions. Different td mutants are inactivated to a different extent and consequently their permissive temperatures also differ (3,12-16). 
In our previous report, we set up a panel of 23 partially inactivated p53 mutants derived from various human tumors. We described their conformation and transactivation activity in yeast, their temperature dependency and capacity to become reactivated by amifostine (17). Subsequently, we analyzed their transactivation activity and temperature dependency in human H1299 cells (18). Functional analysis of separated alleles in yeast (FASAY) $(19,20)$ used for routine detection of p53 mutations allowed us to collect several new td mutants. In this study, we describe the transactivating activity of nine of them in yeast cells. We extensively analyzed their temperature dependency, discriminativity and capacity to become reactivated by amifostine. Analysis of six of the p 53 td mutants was also performed in transiently transfected human H1299 cells.

\section{Materials and methods}

FASAY. FASAY was performed as previously described $(20,21)$. Total RNA was purified using RNeasy Mini Kit (Qiagen). cDNA was synthesized by SuperScript II (Life Technologies) using oligo $(\mathrm{dT})_{12}$ as a primer. PCR was performed using primers P3 (5'-CCT-TGC-CGT-CCC-AAG-CAA-TGG-ATG-AT-3'), P4 (5'-ACC-CTT-TTT-GGA-CTT-CAG-GTG-GCT-GGAGT-3'), and $P f u$ DNA Polymerase (Stratagene). Yeast cells were co-transformed with the PCR product, linearized pSS16, and the salmon sperm DNA carrier (Life Technologies) by the lithium acetate procedure (19). Transformed yeast cells were plated on minimal medium lacking leucine and with a low amount of adenine $(5 \mu \mathrm{g} / \mathrm{ml})$, followed by incubation at $35^{\circ} \mathrm{C}$ for 2-3 days, and then at room temperature for 2-3 days.

Recovery of the p53-expressing plasmid from yeast and sequencing of the p53 cDNA. Yeast cells of individual yeast colonies were harvested, resuspended in TSN ( $2 \%$ Triton X-100, $1 \%$ SDS, $100 \mathrm{mM} \mathrm{NaCl}, 10 \mathrm{mM}$ Tris pH 8.0, 1 mM EDTA), and grinded by vortexing with glass beads; plasmid DNA was extracted by the phenol/chloroform procedure. The $p 53$ cDNA was amplified using the P3 and P4 primers and Taq polymerase (Life Technologies) and subjected to agarose gel electrophoresis. The PCR product was purified by the MinElute PCR purification kit (Qiagen) and sequenced by the BigDye Terminator v3.1 cycle sequencing kit (Applied Biosystems) using ABI PRISM 3100 Genetic Analyzer (Applied Biosystems).

Plasmid construction, cell culture and transfection. The p53 cDNAs extracted from the yeast cells were cloned into the p53-pT-REx-DEST30 plasmids using the Gateway ${ }^{\circledR}$ technology (Invitrogen). H1299 cell lines were cultured in RPMI-1640 medium (L-glutamine, $\mathrm{NaHCO}_{3}$ ) supplemented with $10 \%$ fetal calf serum and $1 \%$ penicillin/streptomycin at $5 \% \mathrm{CO}_{2}$ and 32 or $37^{\circ} \mathrm{C}$. To get the H1299/p53 cells expressing the p53 variants, the cells were co-transfected with p53-pT-REx-DEST30 (prepared according to the manufacturer's instructions) and pcDNA6/TR repressing $p 53$ expression (Invitrogen) in a ratio of 1:7 using Lipofectamine ${ }^{\mathrm{TM}} 2000$ (Invitrogen).

Luciferase reporter assay. $\mathrm{H} 1299$ cells were grown to 75\% confluency, co-transfected with p53-pT-REx-DEST30 $(1 \mu \mathrm{g})$, cmv- $\beta$ gal internal control plasmid $(1 \mu \mathrm{g})$ and the luciferase reporter plasmids $(1 \mu \mathrm{g})$ containing various p53-response elements: p21luc, baxluc or RGCluc (22) using Lipofectamine 2000 and incubated in parallel at 32 and $37^{\circ} \mathrm{C}$ for $42 \mathrm{~h}$. Harvested cells were resuspended in $0.25 \mathrm{M}$ Tris- $\mathrm{Cl}(\mathrm{pH} 7.5)$ and lysed by three cycles of freezing and thawing. Luciferase and $\beta$-galactosidase assays were performed as previously described (23). Relative transactivation activity was expressed as a ratio of normalized luciferase activity of individual p53 mutant and p53 wild-type (wt) activity at $37^{\circ} \mathrm{C}$ on the same responsive element (RE).

Immunoblotting. Yeast or human cells were lysed with buffer containing $150 \mathrm{mM} \mathrm{NaCl}, 50 \mathrm{mM} \mathrm{NaF}, 50 \mathrm{mM}$ Tris (pH 8.0), $5 \mathrm{mM}$ EDTA, $1 \%$ NP40 and $1 \mathrm{mM}$ phenylmethylsulfonylfluoride protease inhibitor on ice for $30 \mathrm{~min}$, and the cell extract was centrifuged at $17,000 \mathrm{~g}$ for $30 \mathrm{~min}$ to remove cell debris. Equal amounts of the supernatant proteins were resolved by $10 \%$ sodium dodecylsulfate polyacrylamide gel electrophoresis (SDS-PAGE) and transferred onto a nitrocellulose membrane. Blots were blocked in $0.1 \%$ Tween-20 and 5\% low-fat milk in PBS for $1 \mathrm{~h}$, probed with anti-p53 antibody DO-1 (kindly provided by B. Vojtesek). Blots were developed with Dako peroxidase-conjugated rabbit anti-mouse immunoglobulin using the ECL chemiluminiscent detection kit (Amersham Pharmacia Biotech).

Reactivation by amifostine. Amifostine (WR2721, Ethyol ${ }^{\circledR}$, S-2[3-aminopropylamino]-ethyl phosphorothioic acid; Schering-Plough), dissolved in water, was spread on the agar plates at a final concentration of $8 \mathrm{mM} 30 \mathrm{~min}$ before seeding yeast cells. The parallel plates with and without amifostine were then incubated at 25,30 and $35^{\circ} \mathrm{C}$ for $3-4$ days.

\section{Results}

Collection of the temperature-dependent p53 mutants. FASAY can determine the functional status of p53 according to the color of the yeast colonies formed by transformed cells on the selection medium. Expression of functional p53 results in the formation of large white colonies, while inactive p53 leads to the development of smaller red colonies. Expression of the td p53 causes formation of pink or two-colored (white-red) colonies $(20,24)$. Based on phenotypes of the yeast colonies, we identified nine p53 td mutants that were not included in our collection of 23 mutants described earlier $(17,18)$. Five of these mutations were recognized as temperature-sensitive ones by others $(11,14,15,25)$, the next four (M133T, V157A, R196G, and R283C), are described here as temperaturedependent for the first time (Table I). The mutants originated from several different tumors, namely colorectal carcinoma, chronic lymphocytic leukemia, diffuse large B-cell lymphoma and glioblastoma. Seven mutations (78\%) were localized in the part of the $p 53$ gene coding for the hydrophobic $\beta$-sandwich structure of the DNA-binding domain. The T211I mutation caused amino acid substitution in the loop and the R283C in the $\alpha$-helix structure of the DNA-binding domain.

Transactivation by the temperature-dependent $p 53$ mutants in yeast. Td 553 mutants often discriminate among their target genes $(3,12,15)$. For routine detection of p53 mutations, we used 
Table I. List of temperature-dependent p53 mutations used in this study.

\begin{tabular}{|c|c|c|c|c|c|c|}
\hline Mutation & $\begin{array}{c}\text { DNA } \\
\text { sequence }\end{array}$ & Source & Exon & $\begin{array}{l}\text { Structural } \\
\text { motif }^{\mathrm{a}}\end{array}$ & $\begin{array}{c}\text { Reported as } \\
\text { somatic/germline } \\
\text { mutation }^{\mathrm{b}}\end{array}$ & Reference \\
\hline M133T & ATG-ACG & $\mathrm{CRC}$ & 5 & $\mathrm{~S} 2$ & $7 / 3$ & - \\
\hline V157F & GTC-TTC & CLL & 5 & $\mathrm{~S} 4$ & $188 / 0$ & Dearth et al (15) \\
\hline V157A & GTC-GCC & DLBCL & 5 & $\mathrm{~S} 4$ & $2 / 0$ & - \\
\hline R196G & CGA-GGA & CLL & 6 & S5 & $2 / 0$ & - \\
\hline T211I & ACT-ATT & CLL & 6 & $\mathrm{~L}$ & $19 / 0$ & Shiraishi et al (14) \\
\hline Y234H & TAC-CAC & glio & 7 & S8 & $27 / 2$ & Campomenosi et al (25) \\
\hline $\mathrm{I} 255 \mathrm{~F}$ & ATC-TTC & CLL & 7 & S9 & $39 / 0$ & Shiraishi et al (14) \\
\hline V272M & GTG-ATG & CLL & 8 & S10 & $103 / 1$ & $\begin{array}{l}\text { Maurici et al (11); } \\
\text { Dearth et al (15) }\end{array}$ \\
\hline $\mathrm{R} 283 \mathrm{C}$ & CGC-TGC & CLL & 8 & $\mathrm{H} 2$ & $27 / 4$ & - \\
\hline
\end{tabular}

CRC, colorectal carcinoma; CLL, chronic lymphocytic leukemia; DLBCL, diffuse large B-cell lymphoma; glio, glioblastoma. ${ }^{\text {a According to }}$ Cho et al (31); baccording to IARC database R15 (http://www-p53.iarc.fr) (1).

the yeast yIG397 cells containing the ribosomal gene cluster (RGC)-derived p53-RE placed upstream of the $A D E 2$ reporter gene (20). To analyze discriminativity and temperaturedependency, we also used the YPH-p21 and YPH-bax strains containing the $\mathrm{p} 53$-specific REs derived from the regulatory regions of the $p 21$ and bax genes, respectively, placed upstream of the ADE2 (25). The yIG397, YPH-p21 and YPH-bax cells transformed with td p53 mutants, p53wt and the hot-spot $\mathrm{R} 175 \mathrm{H}$ mutant as controls, were grown on selection media and incubated at 25,30 and $35^{\circ} \mathrm{C}$ for 4 days. Relative transactivation by p53 was assessed semi-quantitatively according to the color of the resulting yeast colonies using an empirically established seven-step color scale (Fig. 1). The scale comprises the tones of red color exhibited by the yeast colonies depending on the transactivation rate of p53. The endpoints of the scale are represented by the white color of the colonies expressing fully active p53wt (step 1) and the dark red color of the colonies expressing inactive hot spot mutant R175H (step 7) (17).

The pattern of transactivation abilities of individual mutants was considerable variable. The temperature-dependency was confirmed for all tested mutants. Most of them were temperature-sensitive exhibiting elevated or fully restored activity at a lower temperature. The mutants M133T, T211I, I255F, and V272M exhibited the strongest temperature-sensitivity causing the lowest activity at an elevated temperature. The R283C was the only mutant showing clear cold-sensitive (cs) phenotype. It was almost fully active at $35^{\circ} \mathrm{C}$, while losing transactivation activity towards the RGC- and especially the bax-derived RE at a lower temperature. Activity towards the $p 21$-derived RE was temperature-independent and comparable to the activity of p53wt. Thus, this mutant was also clearly discriminating. In addition to the R283C mutant, the R196G and I255F mutants also belonged to the strongest discriminators. By contrast, the T211I, V272, and M133T mutants discriminated only weakly or almost not at all. The discriminators transactivated more efficiently from the $p 21$ - than the bax-derived RE. Considering the overall transactivating activity, there are also reasonable differences among individual mutants. Some mutants, such as

\begin{tabular}{|c|c|c|c|c|}
\hline \multirow{2}{*}{ Mutation } & \multirow[b]{2}{*}{ RE } & \multicolumn{3}{|c|}{ Temperature } \\
\hline & & $25^{\circ} \mathrm{C}$ & $30^{\circ} \mathrm{C}$ & $35^{\circ} \mathrm{C}$ \\
\hline \multirow{3}{*}{$w t$} & RGC & 1 & 1 & 1 \\
\hline & $\mathrm{p} 21$ & 2 & 1 & 1 \\
\hline & bax & 1 & 1 & 1 \\
\hline \multirow{3}{*}{ M133T } & RGC & 2 & 1 & 7 \\
\hline & p21 & 1 & 1 & 7 \\
\hline & bax & 2 & 3 & 6 \\
\hline \multirow{3}{*}{ V157A } & RGC & 2 & 2 & 7 \\
\hline & $\mathrm{p} 21$ & 2 & 4 & 7 \\
\hline & bax & 6 & 6 & 7 \\
\hline \multirow{3}{*}{ V157F } & RGC & 3 & 4 & 5 \\
\hline & $\mathrm{p} 21$ & 1 & 5 & 7 \\
\hline & bax & 7 & 7 & 7 \\
\hline \multirow{3}{*}{$\mathrm{R} 175 \mathrm{H}$} & RGC & 7 & 7 & 7 \\
\hline & p21 & 7 & 7 & 7 \\
\hline & bax & 7 & 7 & 7 \\
\hline \multirow{3}{*}{ R196G } & RGC & 2 & 2 & 2 \\
\hline & $\mathrm{p} 21$ & 1 & 1 & 1 \\
\hline & bax & 5 & 6 & 7 \\
\hline \multirow{3}{*}{$\mathrm{T} 211 \mathrm{I}$} & RGC & 1 & 1 & 2 \\
\hline & $\mathrm{p} 21$ & 1 & 1 & 7 \\
\hline & bax & 1 & 1 & 7 \\
\hline \multirow{3}{*}{$\mathrm{Y} 234 \mathrm{H}$} & RGC & 4 & 7 & 7 \\
\hline & $\mathrm{p} 21$ & 1 & 7 & 7 \\
\hline & bax & 5 & 7 & 7 \\
\hline \multirow{3}{*}{$\mathrm{I} 255 \mathrm{~F}$} & RGC & 1 & 2 & 6 \\
\hline & p21 & 1 & 2 & 1 \\
\hline & bax & 3 & 5 & 7 \\
\hline \multirow{3}{*}{ V272M } & RGC & 1 & 7 & 7 \\
\hline & $\mathrm{p} 21$ & 1 & 7 & 7 \\
\hline & bax & 2 & 7 & 7 \\
\hline \multirow{3}{*}{$\mathrm{R} 283 \mathrm{C}$} & RGC & 6 & 3 & 1 \\
\hline & p21 & 2 & 2 & 2 \\
\hline & bax & 6 & 7 & 2 \\
\hline
\end{tabular}

Figure 1. Transactivation capabilities and temperature dependency of the p53 variants using different p53-responsive elements in yeast cells. Relative transactivation by p53 was semi-quantitatively assessed according to the color of the yeast colonies using an empirically established seven-step color scale (17). 


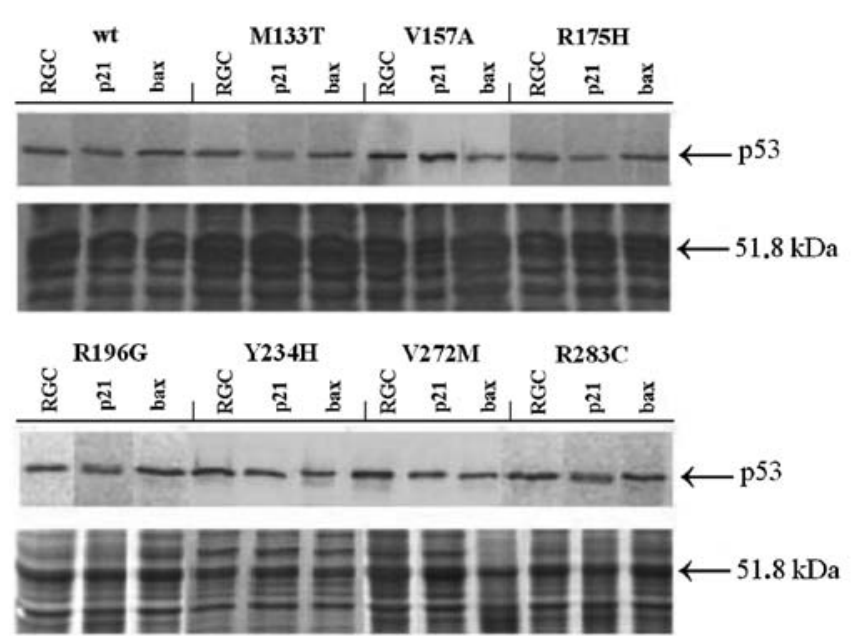

Figure 2. The p53 protein is produced to a similar extent in yeast cells transformed with variants of the $p 53$ gene and luciferase reporters. Cell extracts of the yeast cells were resolved by SDS-PAGE. The p53 protein was visualized by immunoblotting using monoclonal antibody DO-1 (upper panels). To control for sample loading, the cellular proteins were stained with Coomassie Brillliant Blue (lower panels).

$\mathrm{Y} 234 \mathrm{H}$ or $\mathrm{V} 272 \mathrm{M}$, can weakly transactivate only at $25^{\circ} \mathrm{C}$ and are fully inactive at 30 or $35^{\circ} \mathrm{C}$, while some other mutants, such as M133T, T211I and I255F are inactive at $35^{\circ} \mathrm{C}$ and either fully or almost fully active at $30^{\circ} \mathrm{C}$.

The p53 transactivation activity often depends on the intracellular concentration of the p53 protein (3). Therefore, we assessed the expression of all studied p53 variants in all three yeast strains by immunoblotting using the p53-specific antibody DO-1 (Fig. 2). We found that the level of the p53 protein was comparable in all yeast strains and temperatures tested. This documents that the phenotype of the yeast colonies was not affected by the level of p53 in cells.

Transactivation by 553 variants in human and yeast cells. To evaluate the significance of the data obtained in yeast cells, we measured the transactivation ability of some p53 td mutants (M133T, V157F, R196G, T211I, I255F, and R283C) and control variants in human cells. cDNAs coding for the p53 variants were cloned into the pT-REX-DEST30 expression vector. Subsequently, the p53-null H1299 cells were transiently co-transfected with the p53-expression plasmid, internal control plasmid (cmv- $\beta$ gal) and one of the RE-luc reporter plasmids containing $p 21$-, bax- or RGC REs upstream of the luciferase gene. Transfected cells were cultured at 32 and $37^{\circ} \mathrm{C}$ for $42 \mathrm{~h}$, then harvested and used for transactivation assay. Luciferase activity was normalized according to the transfection efficiency using $\beta$-galactosidase as internal control. Relative transactivation activity of individual p53 mutants is shown in Fig. 3. As in the yeast cells, we found considerable differences in the pattern of transactivation activities of individual p53 variants. The mutants differed in their overall activity, temperature sensitivity, as well as discriminativity. The R283C mutant was the most active of all td mutants tested, reaching $34.4 \%$ overall activity of wt p53; it did not exhibit the cold-sensitive pattern observed in transformed yeast cells and its temperature-sensitivity was only weak,

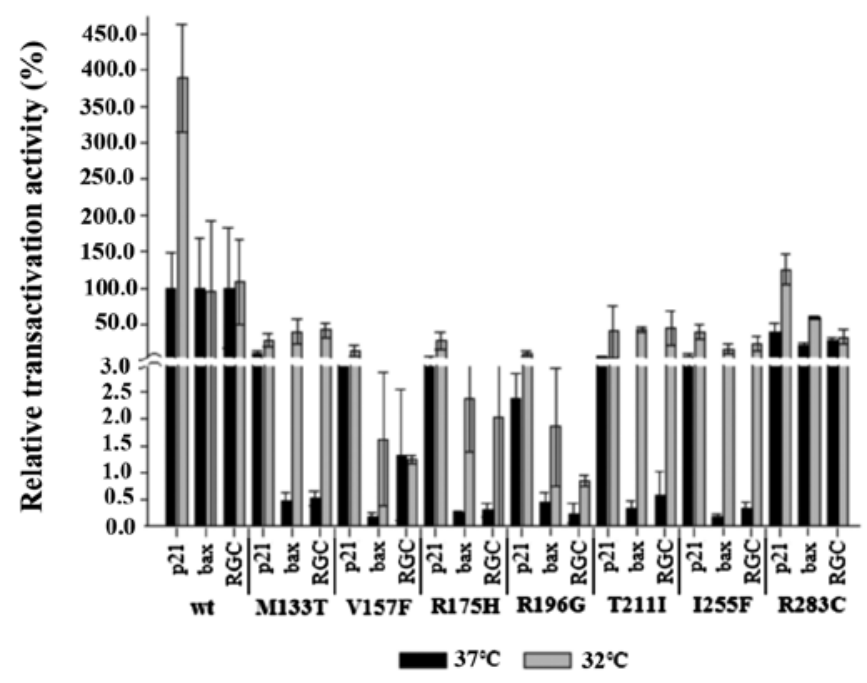

Figure 3. Transactivation capabilities and temperature dependency of the p53 variants using different p53-responsive elements in transiently transfected human H1299 cells. Relative transactivation activity was calculated as luciferase activity found in the cell extracts normalized according to transfection efficiency and the p53 wt activity at $37^{\circ} \mathrm{C}$. Error bars indicate standard deviations in three independent experiments.

reaching reasonable activity even at $37^{\circ} \mathrm{C}$. The $\mathrm{R} 283 \mathrm{C}$ mutant transactivated strongly and almost temperature-independently from the $p 21$-derived RE in yeast cells. In human cells, it retained a rather strong transactivation ability towards this $\mathrm{RE}$ at $37^{\circ} \mathrm{C}$ and this activity was substantially elevated at $32^{\circ} \mathrm{C}$, exceeding even the activity of standard p53, thus fulfilling the criteria of the super-trans mutant (27). The T211I, I255F and M133T mutants exhibited the strongest temperature-sensitivity and they were all transactivation competent. Generally, the low-active V157F and R196G mutants also possessed weak temperature-sensitivity. At the same time, these mutants were the strongest discriminators. The temperature-sensitivity of the M133T, T211I and I255F mutants was host-independent occurring both in yeast and human H1299 cells. Similarly, the strongest discriminators in human cells, the mutants $\mathrm{V} 157 \mathrm{~F}$ and R196G, were strong discriminators in yeast cells as well. These phenomena were not dependent on the overall activity in yeast cells. To test whether or not the transactivation ability of the p53 variants was affected by the $\mathrm{p} 53$ protein concentration in H1299cells, we assessed the expression of all studied p53 variants in transiently transfected cells by immunoblotting using the p53-specific antibody DO-1 (Fig. 4). We verified that the level of the p53 proteins was comparable in all tested cells.

Reactivation of td p53 mutants by amifostine in yeast. We previously showed that the majority of td p53 mutants can be reactivated by amifostine in yeast cells (17). In this study, we tested the ability of all nine td mutants to be reactivated by $8 \mathrm{mM}$ amifostine in 25,30 and $35^{\circ} \mathrm{C}$ towards all three tested REs. The yeast yIG397, YPH-p21 and YPH-bax cells expressing the tested p53 variants were plated in selection medium either containing or lacking $8 \mathrm{mM}$ amifostine and incubated at 25,30 and $35^{\circ} \mathrm{C}$ for $3-4$ days. Then, the relative transactivation by p53 was assessed according to the color of the resulting colonies. The variable effect of amifostine was 


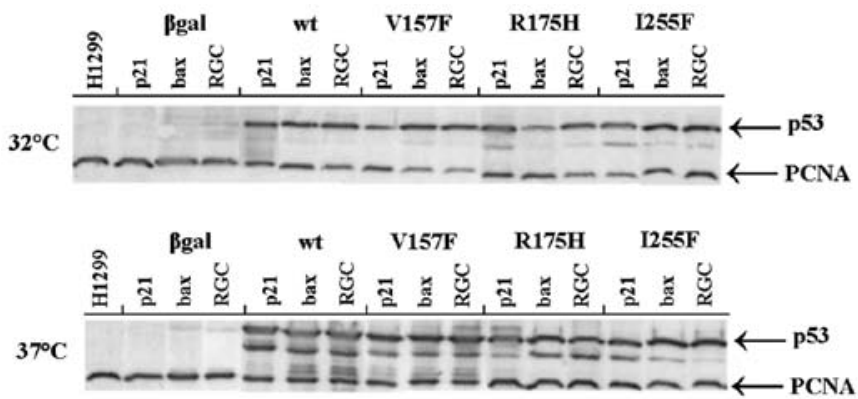

Figure 4. Assessment of the 533 protein level in transiently transfected H1299 cells. Extracts of the H1299 cells were resolved by SDS-PAGE. The p53 protein was visualized by immunoblotting using monoclonal antibody DO-1. To control for sample loading, the PCNA protein was visualized by the PC10 antibody.

detected in eight of them (Fig. 5). The effect of amifostine was reproducibly temperature- and RE-dependent. Only the R196G mutant was completely resistant to amifostine under these conditions. On the other hand, the most sensitive V157F mutant exhibited reactivation to some extent at all tested temperatures and using all tested REs. The rest of the p53 td mutants scored in between these two possibilities. The level of reactivation by amifostine did not follow any rule and was specific for each p53 mutant.

Extent of interference with the p53 transactivation activity depends on the type of amino acid exchange. Our database of $32 \mathrm{td} \mathrm{p53} \mathrm{mutants} \mathrm{derived} \mathrm{from} \mathrm{various} \mathrm{types} \mathrm{of} \mathrm{tumors}$ comprises already four pairs of mutants localized in the same position, namely in codons 157 (causing exchange of valine for alanine or phenylalanine), 234 (tyrosine for cysteine or histidine), 272 (valine for glycine or methionine), and 286 (glutamic acid for lysine or valine). It allowed us to assess the impact of the specific amino acid exchange on the activity of p53 and its capacity to become reactivated by amifostine in yeast cells (Fig. 6). The results clearly show that the transactivation by p53, its temperature dependency and discriminativity, as well as the capacity to become reactivated by amifostine depend not only on the position of amino acid substitution in the p53 protein but also on its specificity of exchanged amino acids.

\section{Discussion}

In the present study we described nine temperature-dependent (td) p53 mutants that were detected in several different tumor types during routine analysis of the p53 status by FASAY. Temperature-dependency of five of these mutants was reported earlier $(11,14,15,25)$. Four of them, M133T, V157A, R196G, and $\mathrm{R} 283 \mathrm{C}$, are described as temperature-dependent in this study for the first time. Nevertheless, there are other p53 mutants in the same positions that have been recognized as temperaturedependent. For example, the mutant bearing leucine instead of arginine in position 196 (R196L) and two mutants in position 283 (R283H, R283P) were reported as temperature-sensitive $(3,12,14,15,26,28)$. We also present the $\mathrm{V} 157 \mathrm{~F}$ mutation previously described (15).

The temperature-dependent character of the p53 mutants is not obvious, and even if assessed, its impact is unclear.

\begin{tabular}{|c|c|c|c|c|}
\hline \multirow{2}{*}{ Mutation } & \multirow[b]{2}{*}{$\mathrm{RE}$} & \multicolumn{3}{|c|}{ Temperature } \\
\hline & & $25^{\circ} \mathrm{C}$ & $30^{\circ} \mathrm{C}$ & $35^{\circ} \mathrm{C}$ \\
\hline \multirow{3}{*}{$\mathrm{wt}$} & RGC & 1 & 1 & 1 \\
\hline & p21 & 2 & 1 & 1 \\
\hline & bax & 1 & 1 & 1 \\
\hline \multirow{3}{*}{ M133T } & RGC & 2 & 1 & $7-5$ \\
\hline & p21 & 1 & 1 & $7 \rightarrow 5$ \\
\hline & bax & 2 & 3 & $6 \rightarrow 3$ \\
\hline \multirow{3}{*}{ V157A } & RGC & 2 & 2 & 7 \\
\hline & p21 & 2 & $4 \rightarrow 2$ & $7 \rightarrow 6$ \\
\hline & bax & $6 \rightarrow 5$ & 6 & 7 \\
\hline \multirow{3}{*}{$\mathrm{V} 157 \mathrm{~F}$} & RGC & $3 \rightarrow 1$ & $4 \rightarrow 2$ & 5 \\
\hline & p21 & 1 & $5 \rightarrow 2$ & 7 \\
\hline & bax & $7-5$ & $7 \rightarrow 6$ & $7 \rightarrow 5$ \\
\hline \multirow{3}{*}{$\mathrm{R} 175 \mathrm{H}$} & RGC & 7 & 7 & 7 \\
\hline & p21 & 7 & 7 & 7 \\
\hline & bax & 7 & 7 & 7 \\
\hline \multirow{3}{*}{ R196G } & RGC & 2 & 2 & 2 \\
\hline & p21 & 1 & 1 & 1 \\
\hline & bax & 5 & 6 & 7 \\
\hline \multirow{3}{*}{$\mathrm{T} 211 \mathrm{I}$} & RGC & 1 & 1 & 2 \\
\hline & p21 & 1 & 1 & 7 \\
\hline & bax & 1 & 1 & $7 \rightarrow 6$ \\
\hline \multirow{3}{*}{$\mathrm{Y} 234 \mathrm{H}$} & RGC & $4 \rightarrow 2$ & $7 \rightarrow$ & $7-5$ \\
\hline & p21 & 1 & 7 & $7 \rightarrow 6$ \\
\hline & bax & 5 & 7 & 7 \\
\hline \multirow{3}{*}{$\mathrm{I} 255 \mathrm{~F}$} & RGC & 1 & $2 \rightarrow 1$ & \\
\hline & p21 & 1 & $2 \rightarrow 1$ & 1 \\
\hline & bax & 3 & 5 & $7 \rightarrow 6$ \\
\hline \multirow{3}{*}{$\mathrm{V} 272 \mathrm{M}$} & RGC & 1 & 7 & $-7 \rightarrow 5$ \\
\hline & p21 & 1 & 7 & 7 \\
\hline & bax & 2 & 7 & 7 \\
\hline \multirow{3}{*}{ R $283 C$} & RGC & 6 & 3 & 1 \\
\hline & $\mathrm{p} 21$ & $2 \rightarrow 1$ & $2 \rightarrow 1$ & 2 \\
\hline & bax & $6-5$ & 7 & 2 \\
\hline
\end{tabular}

Figure 5. The effect of amifostine on the activity of the p53 mutants. The yeast yIG397, YPH-p21 and YPH-bax cells expressing the tested p53 variants were plated in selection medium either containing or lacking $8 \mathrm{mM}$ amifostine and incubated at 25,30 and $35^{\circ} \mathrm{C}$ for 3-4 days. Relative transactivation by p53 was semi-quantitatively assessed according to the color of the yeast colonies using an empirically established seven-step color scale (17). Arrows indicate the amifostine-induced shift of the p53 transactivation activity.

Although there is no doubt that these p53 mutants represent a specific group of mutants, the overwhelming majority of clinical trials does not take this property into consideration. First, with the exception of some functional methods, FASAY in particular, temperature-dependency is not detectable by conventional analyses of the p53 status. Second, even exact determination of the temperature-dependency of the $\mathrm{p} 53$ variants found in tumors is not unambiguous. The extent of damage of the p53 activity resulting from a temperature-dependent mutation ranges from slight, leaving activity of the resulting p53 protein almost unrecognizable from its standard variant, up to extensive, resulting in protein with very low activity. This lack of clarity is well documented by authors attempting to clearly and measurably delimit and define criteria to select 


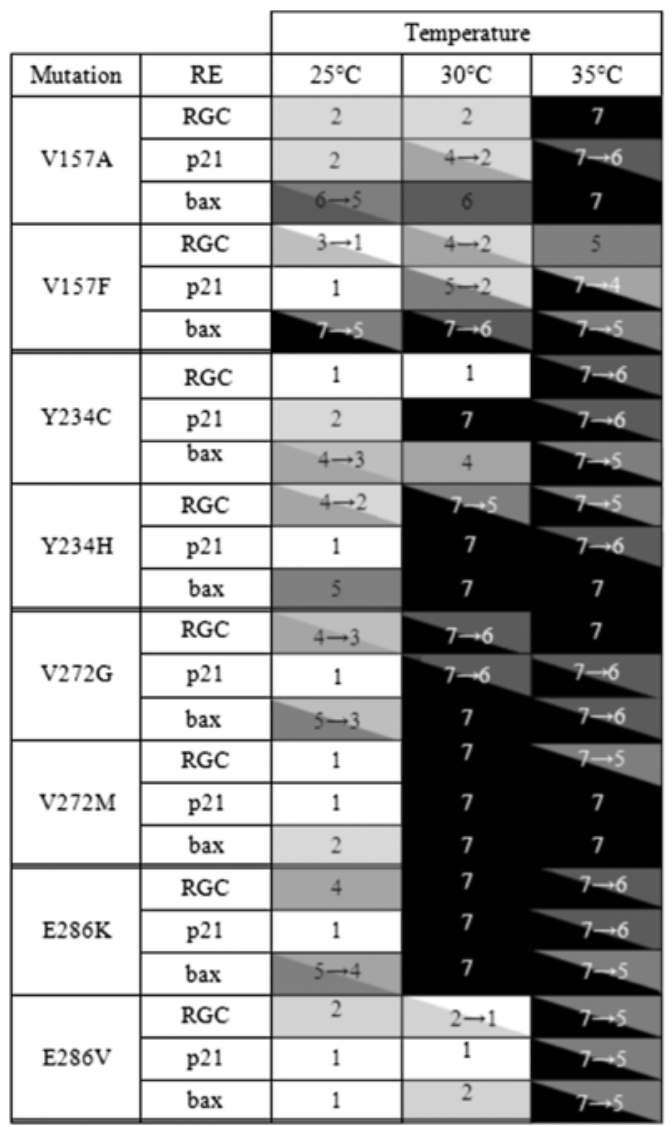

Figure 6. Comparison of transactivation capabilities, temperature dependency, discriminativity, and sensitivity to amifostine of four pairs of p53 mutants. Relative transactivation by 53 was semi-quantitatively assessed according to the color of the yeast colonies by means of an empirically established seven-step color scale (17). Arrows indicate the amifostine-induced shift of the p53 transactivation activity.

td p53 mutants (14). In addition, even p53wt has been recognized as a temperature-sensitive protein and this fact illustrates how difficult it is to define the temperature-dependency of its mutants $(17,29,30)$. Altogether, the td p53 mutants do not comprise a uniform group. Therefore, behavior of each mutant has to be tested and examined individually. The data presented in this study clearly support this view. Therefore, our findings contribute to the general conclusions outlined below.

It has previously been postulated that the majority of td mutations is localized in the $\beta$-sandwich-coding region of the $p 53$ gene. Out of the nine td mutants analyzed in this work, seven were indeed mapped in this region.

The majority of the discriminating p53 mutants have been repeatedly shown to prefer the $p 21$ - to the bax-derived RE. This has even led to the conclusion that abrogation of apoptosis represents the main target of p53 inactivation during oncogenic transformation $(12,26)$. Our discriminators clearly accomplished this rule. Nevertheless, we detected a few exceptions in our previous collection of td p53 mutants, namely Y234C and P98A. Markedly, if a p53 mutant prefers the bax-derived RE or uses both REs equally in yeast cells, it usually keeps this pattern also in human cells. This is the case of the P98A and Y126C mutants and, also to some extent, of the T211I, V272M, Y234C and R337C mutants $(17,18)$.
The cold-sensitive p53 mutants are rather rare. In this study, we described R283C exhibiting a clear cold-sensitive pattern in yeast cells. In human cells, R283C was only weakly temperature-dependent; it was the most active of the td mutants tested and it reached reasonable activity even at $37^{\circ} \mathrm{C}$. Notably, the P98A, P222L, R337C and L344R mutants classified as cold-sensitive in yeast were the only mutants from the previous collection of $23 \mathrm{td}$ mutants which retained some transactivating ability in human cells towards all three promoters also at $37^{\circ} \mathrm{C}$. The P98A mutant transactivated the $p 21$-derived RE with the same efficiency as p53wt at $37^{\circ} \mathrm{C}$ and with higher efficiency at this temperature than at $32^{\circ} \mathrm{C}(17,18)$. It seems that although it is not cold-sensitivity that characterizes this group of mutants in human cells, once they are cold-sensitive in yeast cells, it categorizes them into a specific group of mutants exhibiting a specific pattern of transactivation activity.

Specificity of amino acid exchange in p53 mutants is important. Our previous panel of 23 td p53 mutants included two mutants with replaced glutamic acid in position 286 for either lysine or valine. These two mutants differed considerably in their transactivation abilities in yeast (17) as well as in human cells (18). The mutant containing valine was significantly more active than the mutant that had lysine in the same position. In the present study, we confirmed this result and further extended it for the next three pairs of mutants. We found similarly strong differences in the activities of Y234C and $\mathrm{Y} 234 \mathrm{H}$, while pairs of mutants V157A/F and V272G/M behaved more similarly, though not equally. The impact of specific amino acid exchange on the p53 protein activity is a function not only of the size of the amino acid but also of its reactivity and flexibility. Similar results have previously been reached and in several cases even connecting these differences with a different clinical impact of the mutants (7).

Despite some differences and minor discrepancies, there is substantial concordance between the activity patterns of different p53 mutants in yeast and human H1299 cells. This conclusion confirms our own previous results as well as results reported by others $(15,18)$. This strongly justifies employment of the yeast cell-derived systems, such as FASAY, for reliable detection of p53 mutations of human origin.

In conclusion, we can confirm that despite some similar activity patterns, there is no steady rule to categorize the td p53 mutants in relation to their transactivation activity or their reactivation capacity. Each missense mutation affects specific amino acid interactions within the p53 molecule or its contact with DNA in a unique way or alters the overall conformation of the DNA-binding domain (8). Thus, it is necessary to analyze each p53 mutant individually.

\section{Acknowledgements}

This study was supported by grant NS/10448-3 of the Internal Grant Agency of the Ministry of Health of the Czech Republic.

\section{References}

1. Petitjean A, Mathe E, Kato S, Ishioka C, Tavtigian SV, Hainaut $P$ and Olivier M: Impact of mutant p53 functional properties on TP53 mutation patterns and tumor phenotype: lessons from recent developments in the IARC TP53 database. Hum Mutat 28: 622-629, 2007. 
2. Blagosklonny MV: P53 from complexity to simplicity: mutant p53 stabilization, gain-of-function, and dominant-negative effect. FASEB J 14: 1901-1907, 2000.

3. Resnick MA and Inga A: Functional mutants of the sequencespecific transcription factor $\mathrm{p} 53$ and implications for master genes of diversity. Proc Natl Acad Sci USA 100: 9934-9939, 2003.

4. Monti P, Ciribilli Y, Jordan J, Menichini P, Umbach DM, Resnick MA, Luzatto L, Inga A and Fronza G: Transcriptional Functionality of germ line p53 mutants infuences cancer phenotype. Clin Cancer Res 13: 3789-3795, 2007.

5. Varley JM, McGown G, Thorncroft M, James LA, Margison GP Forster G, Evans DGR, Harris M, Kelsey AM and Birch JM: Are there low-penetrance TP53 alleles? Evidence from childhood adrenocortical tumors. Am J Hum Genet 65: 995-1006, 1999.

6. Ribeiro RC, Sandrini F, Figueiredo B, Zambetti GP, Michalkiewicz E, Lafferty AR, DeLacerda L, Rabin M, Cadwell C, Sampaio G, et al: An inherited p53 mutation that contributes in a tissue-specific manner to pediatric adrenal cortical carcinoma. Proc Natl Acad Sci USA 98: 9330-9335, 2001.

7. Zambetti GP: The p53 mutation 'gradient effect' and its clinical implications. J Cell Physiol 213: 370-373, 2007.

8. Kato S, Han SY, Liu W, Otsuka K, Shibata H, Kanamura R and Ishioka $\mathrm{C}$ : Understanding the function-structure and functionmutation relatiohship of p53 tumor suppressor protein by high-resolution missense mutation analysis. Proc Natl Acad Sci USA 100: 8424-8429, 2003.

9. Olivier M, Hollstein M and Hainaut P: TP53 mutations in human cancers: Origins, consequences, and clinical use. Cold Spring Harb Perspect Biol 2: a001008, 2010.

10. North S, Pluquet O, Maurici D, El-Ghissassi F and Hainaut P: Restoration of wild-type conformation and activity of a temperature-sensitive mutant of p53 (p53(V272M)) by the cytoprotective aminothiol WR1065 in the esophageal cancer cell line TE-1. Mol Carcinog 33: 181-188, 2002.

11. Maurici D, Monti P, Campomenosi P, North S, Frebourg T, Fronza G and Hainaut P: Amifostine (WR2721) restores transcriptional activity of specific p53 mutant proteins in a yeast functional assay. Oncogene 20: 3533-3540, 2001.

12. Di Como C and Prives C: Human tumor-derived p53 proteins exhibit binding site selectivity and temperature sensitivity for transactivation in yeast-based assay. Oncogene 19: 2527-2539, 1998.

13. Bullock AN, Henckel J and Fersht AR: Quantitative analysis of residual folding and DNA binding in mutant p53 core domain: definition of mutant states for rescue in cancer therapy. Oncogene 19: 1245-1256, 2000.

14. Shiraishi K, Kato S, Han SY, Liu W, Otsuka K, Sakayori M, Ishida T, Takeda M, Kanamaru R, Ochuchi N and Ishioka C: Isolation of temperature-sensitive p53 mutations from a comprehensive missense mutation library. J Biol Chem 279: 348-355 2004.

15. Dearth LR, Qian H, Wang T, Baroni TE, Zeng J, Chen SW, Yi SY and Brachmann RK: Inactive full-length p53 mutants lacking dominant wild-type p53 inhibition highlight loss of heterozygosity as an important aspect of p53 status in human cancers. Carcinogenesis 28: 289-298, 2007.

16. Joerger AC and Fersht AR: Structure-function-rescue: the diverse nature of common p53 cancer mutants. Oncogene 26: 2226-2242, 2007.
17. Grochova D, Vankova J, Damborsky J, Ravcukova B, Smarda J, Vojtesek B and Smardova J: Analysis of transactivation capability and conformation of p53 temperature-dependent mutants and their reactivation by amifostine in yeast. Oncogene 27: 1243-1252, 2008.

18. Slovackova J, Grochova D, Navratilova J, Smarda J and Smardova J: Transactivation by temperature-dependent $\mathrm{p} 53$ mutants in yeast and human cells. Cell Cycle 9: 2141-2148, 2010.

19. Ishioka C, Frebourg T, Yan Yx, Vidal M, Friend SH, Schmidt S and Iggo R: Screening patients for heterozygous p53 mutations using a functional assay in yeast. Nat Genet 5: 124-129, 1993 .

20. Flaman JM, Frebourg T, Moreau V, Charbonnier F, Martin C, Chappuis P, Sappino AP, Limacher JM, Bron L, Benhattar J, et al: A simple p53 functional assay for screening cell lines, blood, and tumors. Proc Natl Acad Sci USA 92: 3963-3967, 1995.

21. Smardova J, Nemajerova A, Trbusek M, Vagunda V and Kovarik J: Rare somatic p53 mutation identified in breast cancer: a case report. Tumor Biol 22: 59-66, 2001.

22. Friedlander P, Haupt Y, Prives C and Oren M: A mutant p53 that discriminates between $\mathrm{p} 53$-responsive genes cannot induce apoptosis. Mol Cell Biol 16: 4961-4971, 1996.

23. Navratilova J, Horvath V, Kozubik A, Lojek A, Lipsick J and Smarda J: p53 arrest growth and induces differentiation of v-Myb-transformed monoblasts. Differentiation 75: 592-604, 2007.

24. Pavlova S, Mayer J, Koukalova H and Smardova J: High frequency of temperature-sensitive mutations of p53 tumor suppressor in acute myeloid leukemia revealed by functional assay in yeast. Int J Oncol 23: 121-131, 2003.

25. Campomenosi P, Monti P, Aprile A, Abbondandolo A, Frebourg T, Gold B, Crook T, Inga A, Resnick MA, Iggo R and Fronza G: p53 mutants can ften transactivate promoters containing a p21 but not Bax or PIG3 responsive elements. Oncogene 20: 3573-3579, 2001.

26. Flaman JM, Robert V, Lenglet S, Moreau V, Iggo R and Frebourg T: Identification of human p53 mutations with differential effects on the bax and $\mathrm{p} 21$ promoters using functional assay in yeast. Oncogene 16: 1369-1272, 1998.

27. Inga A, Monti P, Fronza G, Darden T and Resnick M: p53 mutants exhibiting enhanced transcriptional activation and altered promoter selectivity are revealed using a sensitive, yeastbased functional assay. Oncogene 20: 501-513, 2001.

28. Fulci G, Ishii N, Maurici D, Gernert KM, Hainaut P, Kaur B and Van Metr EG: Initiation of human astrocytoma by clonal evolution of cells with progressive los sof p53 functions in a patient with a $283 \mathrm{H}$ TP53 germ-line mutation: Evidence for precursor lesion. Cancer Res 62: 2897-2905, 2002.

29. Hansen S, Hupp TR and Lane DP: Allosteric regulation of the thermostability and DNA binding activity of human p53 by specific interacting proteins. J Biol Chem 271: 3917-3924, 1996.

30. Xirodimas DP and Lane DP: Molecular evolution of the thermosensitive PAb1620 epitope of human 553 by DNA shuffling. J Biol Chem 274: 28042-28049, 1999.

31. Cho Y, Gorina S, Jeffrey PD and Pavletich NP: Crystal structure of a p53 tumor suppressor-DNA complex: understanding tumorigenic mutations. Science 265: 346-355, 1994. 